準は、基本的に接触感染および飛沫感染による感染症対応の病室仕 様となっており、現在は空気感染症である結核患者の入院は想定さ れていない。

またこの通知では、二類感染症に対応する第二種感染症指定医療 機関においても「1〜2床の空気感染に対応できる病室も設けるこ とが望ましい。その時の施設基準は第一種病室に準ずる」との記述 があるが、第一種病室は表 2 のよな治療法が未確立の強い感染力 と致死率を持つ感染症に対応寸る病室であるので、治療法が確立さ れている結核に対応する病室としては、過度な施設要件である。

一方で、結核病床の施設基準については、表 1 にみたように曖昧 な要件しか示されておらず、病室単位で患者を収容する際にどのよ うな配慮が求められるのかについては明らかにされていない。

つまり今般、空気感染である結核が二類感染症に位置づけられた ため、二類感染症のための医療機関として「結核病床を有する結核 指定医療機関」と「第二種病室を有する第二種感染症指定医療機関」 の 2 種類が併存することとなり、そのいずれに関しても、病室単位 で結核患者を収容する際に求められる施設基準が示されていない状 況にある。

\section{1-3. 目的}

1-1で述べたように、わが国において今後、病棟もしくは病院単 位で結核患者の入院治療を行う状況となることは考えにくく、病室 単位で収容・治療するための施設基準を検討することは、喫緊の課 題であると考える。そこで本稿では、結核患者を収容するための医 療機関に求められる施設要件を検討した結果について報告する。

\section{2. 検討の方法}

検討のための材料として、結核に関する文献と、既存の医療機関 の施設基準とを参考資料として収集した。

米国においては、C D C (Centers for Disease Control and Prevention ; 疾病管理予防センター) による結核感染防止のガイド ライン 2) が公表されている。CDCの各ガイドラインは、最新の知 見による科学的根拠を反映させた改訂版が随時公表されるため、 $\mathrm{E}$ BM (Evidence Based Medicine; 科学的根拠に基づいた医療) 実践 のための資料として世界各国の医療関係者らに広く活用されている。 さらに、米国建築家協会による医療施設の設計ガイドライン ${ }^{7)} に お$ いても引用されるなど、施設基準における科学的根拠として位置づ けられている。

わが国の文献資料としては、厚生労働省が定める施設基準 1) 3) の ほか、財団法人結核予防会による文献 ${ }^{4)}$ が最新の結核医療に関する 情報源として入手可能である。

今回の検討では、まずこれらの文献資料 1) 25) 3) 4) 5) 6) 7) を参照し、 各資料において記載・推奨されている事項について整理した。その際、 (1)感染管理に関する事項（他の患者や職員への感染を防止する観点） と、(2)適切な療養環境の確保のための事項（長期入院を強いられる 患者のQOL 〔生活の質〕を確保する観点）とに大きく分けて、事 項の体系化（表 4）を行った上で、この軸にあわせて各文献におけ る記載・推奨内容を分類し、比較表を作成した。

次に感染管理・建築設計・環境工学等の専門家からなる研究班注3) を組織し、作成した比較表を議論の対象として、わが国の結核医療、 病院管理および病院建築の実情を勘案しながら各事項の吟味・検討
表 2 感染症法における疾患分類と感染経路

\begin{tabular}{|c|c|c|}
\hline 分類 & 疾患名 & 感染経路 \\
\hline \multirow[t]{7}{*}{ 一類感染症 } & エボラ出血熱 & 接触感染（感染者の体液・血液） \\
\hline & クリミア・コンゴ出血熱 & ダニに噛まれて感染 \\
\hline & 痘そう（天然痘） & 飛沫感染・接触感染 \\
\hline & 南米出血熱 & げっ歯類の唾液・排泄物、感染者との接触 \\
\hline & ペスト & ノミ媒介、感染者の血痰に含まれる菌 \\
\hline & マールブルグ病 & ヒトーヒトは接触感染、野生動物からの感染 \\
\hline & ラッサ熱 & 飛沫感染・接触感染 \\
\hline \multirow[t]{5}{*}{ 二類感染症 } & 急性灰白髄炎（ポリオ） & 経口感染 \\
\hline & \begin{tabular}{|l} 
結核 \\
\end{tabular} & 空気感染 \\
\hline & ジフテリア & 飛沫感染 \\
\hline & SARS & 飛沫感染 \\
\hline & 鳥インフルエンザ (H5N1) & $\begin{array}{l}\text { 知見は限定的。飛沫感染・接触感染か (トリと } \\
\text { の濃厚な接触の後に感染した症例が多いため) }\end{array}$ \\
\hline
\end{tabular}

表 3 感染症指定医療機関の施設基準（建築設備関連の主なもの）1）

\begin{tabular}{|c|c|c|}
\hline 事項 & 第一種病室 & 第二種病室 \\
\hline $\begin{array}{l}\text { 対応する感染症の感染 } \\
\text { 経路 }\end{array}$ & 接触感染・飛沫感染 $\cdot$ 空気感染 & 接触感染・飛沫感染 \\
\hline 前室と室定員 & 前室つき個室 & 規定なし \\
\hline トイレ・シャワー設備 & 病室内 & 病室内または病室に隣接 \\
\hline 病室床面積 & $15 \mathrm{~m}^{2}$ 以上（新築の場合） & 規定なし \\
\hline 天井高 & 2.4 m以上（新築の場合） & 規定なし \\
\hline 空気の漏洩 & 内部の空気が外部に漏れない & 規定なし \\
\hline 仕上げ & 清掃や消毒が容易な床・壁 & 清掃や消毒が容易な床・壁 \\
\hline 空調設備 & \begin{tabular}{|l|} 
全外気方式または十分な能力の \\
フィルターによる再循環方式
\end{tabular} & 規定なし \\
\hline 給気設備 & \begin{tabular}{|l|} 
単独 \\
十分な能力のフィルターまたは \\
空気の逆流防止機能付
\end{tabular} & 規定なし \\
\hline 排気 & $\begin{array}{l}\text { 単独 } \\
\text { 十分な能力のフィルター付 }\end{array}$ & 規定なし \\
\hline 院圧制御 & 院圧制御が可能 & 規定なし \\
\hline 換気 & 十分な換気 & 規定なし \\
\hline 排水 & 専用の排水処理設備 & 規定なし \\
\hline 手洗い設備 & $\begin{array}{l}\text { 病室と前室にそれぞれ設置 } \\
\text { 手の指を使わずに操作可能 }\end{array}$ & $\begin{array}{l}\text { 病室とトイレに設置 } \\
\text { 手の指を使わずに操作可能 }\end{array}$ \\
\hline 病室内 $の$ 給水 $\cdot$ 給湯 & 逆流防止機能 & 逆流防止機能 \\
\hline 面会設備 & 設置 & 規定なし \\
\hline 病室内備品 & 電話機・テレビ設置 & 電話機・テレビ設置 \\
\hline
\end{tabular}

表 4 既往の文献・規準等において言及されている事項の体系化

\begin{tabular}{|c|c|c|}
\hline 1 & 感染 & 管理（他の患者や職員への感染を防止する観点） \\
\hline & 1.1 & 施設設備 \\
\hline & & 1. 1.1 病室の配置 \\
\hline & & 1.1 .2 病室定員 \\
\hline & & 1.1 .3 衛生設備 \\
\hline & & 1.1.4 空調設備 \\
\hline & & 1.1.5 特定区域の設定 \\
\hline & 1.2 & 病原菌の拡散防止 \\
\hline & & 1.2 .1 気流の制御 \\
\hline & & 1.2 .2 病原菌数の削減 \\
\hline & 1.3 & 病室内への立ち入り者 (医療スタッフ等) の安全確保 \\
\hline & & 1.3.1 病室内の空気流の方向 \\
\hline & & 1.3 .2 マスクの使用 \\
\hline & 1.4 & 検査・処置のための諸室 \\
\hline & & 1.4 .1 検査室 \\
\hline & & 1.4 .2 処置室 \\
\hline & 1.5 & 運用の評価体制 \\
\hline & & 1.5 .1 院内感染対策委員会 \\
\hline & & 1.5 .2 チェックと記録 \\
\hline 2 & 適切: & な療養環境の確保（長期入院を強いられる患者のQＯLを確保する観点） \\
\hline & 2.1 & 病室の療養環境 \\
\hline & & 2.1.1 病室面積 \\
\hline & & 2.1 .2 病室天井高 \\
\hline & & 2.1 .3 病室内の設備 \\
\hline & 2.2 & 病室外の療養環境 \\
\hline & & 2.2.1 特定区域の設定（特定区域の位置づけと機能） \\
\hline & & 2.2 .2 特定区域のしつらい \\
\hline & 2.3 & 患者の行動制限 \\
\hline & & 2.3.1 病室・特定区域内に滞在するための動機付け \\
\hline & & 2.3 .2 病室・特定区域外に出る際の注意事項 \\
\hline & 2.4 & 運用の評価体制 \\
\hline & & 2.4.1 チェックと記録 \\
\hline
\end{tabular}


を行った。事項によっては、複数の文献のあいだで記載内容が相対 するものがあったが、その場合は研究班メンバーの意見を踏まえて 採用する推奨事項を決定した。

なお検討にあたっては、主として急性期病院において病室単位で 結核患者を収容する場合を想定しており、数年に亘る入院治療が必 要となる多剂耐性結核の患者は、結核専門の医療機関に入院するこ とが適当とした上で、議論を行った。

以上のプロセスにより、結核患者を収容する医療機関の施設基準 として適切と思われる要件をとりまとめた。

次節に示寸施設基準試案では、次のように推奨の度合いに応じて 表現を使い分けている。

・必須事項（‥すること。ㄷとする。ㄴ.しなければならない。）：必須 の実施事項と判断される施設基準。

・推奨事項（‥が望ましい。）：できるだけ実施してほしいが条件によ っては実施困難な場合も想定される施設基準。

また各項目に付した数字は、根拠として参照した文献の番号（巻 末の参照文献リストと対応）を表わす。

\section{3. 結果}

\section{3-1．結核患者を収容する医療機関の施設基準試案}

結核患者の収容に必要と考えられる施設基準試案を検討した結果、 以下に示寸 32 項目が挙げられた。

\section{(病室の面積・構造等)}

\section{[1] 病室は原則として個室とすること ${ }^{1)}{ }^{2)}$ 。}

感染対策上の理由に加えて、病床利用の効率性を確保する観点か らも、病室は原則として個室とすること。

ただし薬剤耐性パターンが同一(薬剤耐性なしも含む)である患者、 あるいは、有効な治療により感染性がきわめて減少している患者の 場合は、2名以上を同じ病室（多床室）に収容することができる。

結核患者を収容する病室を複数整備する際には、当該病室群を集 めて配置するとよい。これは、コストや感染の危険を減らすと共に、 結核患者に対して適切な治療を提供し、空調設備等に関する対策の 導入・維持を行う上で好都合なためである ${ }^{2)}$ 。建築構造や施設の維 持管理方法にもよるが、横一列（建物の 1 翼など）あるいは縦一列（ 複数階の端部の病室など）にまとめて整備する方法が考えられる ${ }^{2)}$ 。

なお重症患者を収容する場合には、個室内の異変を察知しや寸い ような工夫が必要である。

\section{[2]病室に隣接して、結核患者が自由に行動できる特定区域を設け}

\section{ることが望ましい ${ }^{3)}$ 。}

結核患者の収容期間は他の感染症と比較して長期にわたるため、 患者のQOL (生活の質) 確保の観点から、専用の食堂や談話室等 の共用空間を含む特定区域を設け、病室外に出ることができるよう にすることが望ましい。

特定区域の広さやしつらいは、収容患者の入院期間や、当該病室 の使用頻度等を勘案して設定する。

また現在入院中の患者に必要な予防策を表す標識・サイン等を、 病室および特定区域の出入口付近に表示できるようにすること ${ }^{1)}$ 。

[ 3 ] 病室は前室（病室に隣接し、当該病室に外部から出入りする際 に常に経由する室をいう。以下同じ。)を有していることが望ましい1) 2) 4) 5)。
前室は必ずしも必要でないが、病室扉を開放する際に廊下一飛沫 核が拡散する可能性を小さくする効果がある ${ }^{2)}$ 。室内空気の外部流出 を防ぐためには、前室は病室に対して陽圧に保つ必要があるが、易 感染患者を収容する場合などは患者の状態に応じて陰圧・陽圧を設 定する必要がある（3-2 節 Bを参照のこと）。

\section{［4］易感染性の患者を収容する病室には前室を設けること。}

結核を合併した易感染患者を収容する場合には、前室と廊下の間 の圧の関係を、必要性に応じて変えてよい2）5）（3-2節 Bを参照の こと。)

[ 5] 病室面積はトイレ・シャワーを除いて $15 \mathrm{~m}^{2} /$ 室以上とするこ とが望ましい1)。

結核患者は他の感染症患者と比較して入院期間が長く、入院治療 を開始してから退院するまで平均して 2 か月間を要する。特に入院 初期の排菌状態にある期間は、行動範囲が病室内に限定されること から、患者のQＯLを確保するために、病室面積は $15 \mathrm{~m}^{2} /$ 室以上と することが望ましい1)。

\section{[6]病室または特定区域内にトイレ及びシャワー設備を設けること 2)。}

結核患者は一定の期間、行動範囲が限定されることを考慮し、病 室内にトイレ及びシャワー設備を設けることが望ましい。既存施設 等で病室内にトイレ・シャワー設備を設けることが困難な場合のみ、 トイレ・シャワー設備が病室内になくてもやむを得ない。ただし当 該病室からトイレ・シャワー設備に至るまでの廊下は特定区域とし て、扉等で特定区域外の区域と区画すること ${ }^{1)}$ 。

\section{(病室の空、扉等)}

[ 7 ] 病室の開口部はできる限りふさぐこと 1) 2) 3)。

陰圧を保持し気流方向の適切な制御を容易にするため、病室の窓 を開放不可としたり、設備配管の壁貫通孔等をふさぐなど、不要な 空気の流出入をなくすこと ${ }^{2)}$ 。

陰圧状態を適切に保つために、病室扉の下部等に空気流の通路を 確保すること2)。

\section{[ 8 ] 病室の扉は自閉式とすること ${ }^{2)}{ }^{3)}$ 。}

病室内の空気が流出する危険性を減らすために、病室の扉は自動 的に閉じる構造とすること ${ }^{3)}$ 。扉の開閉時の気流の乱れを少なくする ため、引き戸とすることが望ましい。

\section{(空調換気設備)}

[ 9 ] 病室は原則として陰圧を保持すること 1) 2) 3) 4) 5)。

結核患者収容時の病室は、污染空気（飛沫核）が病室周囲一流出 することがないよう、原則として外部に対して陰圧に保たなければ ならない。圧差は近年の知見によると $2.5 \mathrm{~Pa}$ 以上を設けるものとさ れている2)。

ただし、易感染患者を収容する場合などは、陰圧ではなく陽圧で 運用することもあるが、前室等を利用して外部へ空気が流れ出ない ようにする。

なお陰圧の確認については、項目 25 を参照のこと。

[10] 病室では適切な換気を行うこと ${ }^{2)}$ 。

病室内に浮遊する飛沫核を減らすために、当該病室の換気回数は、 全風量で 1 時間あたり 12 回以上とすること 2) ${ }^{5)}$ 。既存施設の場合、 換気回数は全風量で 1 時間あたり 6 回以上とすること 2) 5)。 最小外気導入量は 1 時間あたり 2 回以上とすること ${ }^{1)}$ 5)。 
[11] 病室内の患者に安全に接することができるよう、空気流の方向 を設定すること ${ }^{2)}$ 。

病室内で職員が処置行為等を行う際、室内気流が職員の作業エリ ア側からベッド (患者) 側へと流れるよう、ベッド位置と吹出口（外 気、給気注4) および吸込口（排気注5)、還気注6)）の位置との関係を 調整すること。

なお吹出口（外気、給気）および吸込口（排気、還気）の設置位置は、 病室外一の空気の流出に影響を与えることが考えられるので、十分 な検討を行うこと。

[12] 施設内の空気は、清潔区域から污染区域へ流れるよう維持する こと ${ }^{2)}$ 。

病室または特定区域の空気が、他の区域一流入することがないよ う、施設内の空気流の方向を設定すること。

[13] 病室または特定区域の空調換気設備は、全排気方式（病室また は特定区域に取り入れた外気をすべて屋外へ排出し、空調機への還 気を行わない方式）が望ましい4)。

全排気方式とすることが困難な場合には、再循環方式（病室また は特定区域からの排気の一部を循環させて給気の一部に用いる方式 をいう。）としてもよい。その場合は次項に準じること。

[14] 病室または特定区域の空調換気設備を再循環方式（病室または 特定区域からの排気の一部を循環させて給気の一部に用いる方式) とする場合には、結核菌を病室内に再流入させないために HEPA フィ ルター注7を備えていること2)。

病室または区域から排出される空気の再循環を行う場合には、 HEPA フィルター付再循環設備を設けること²)。

付加的な殺菌装置として UVGI（紫外線殺菌照射）注8) を利用しても よいが、補助的手段として用いるにとどめ、HEPA フィルターの代用 として用いてはならない。

[15] 病室および特定区域は独立した排気とすること 1) 2) 3) 5)。

病室および特定区域の排気は、逆流によって他の区域を污染する ことがないように、単独排気とすること ${ }^{1)}$ 。

[16] 病室および特定区域からの排気は直接屋外へ排出してょい。た だし施設の立地条件によっては、排気設備にHEPA フィルターを設置 すること ${ }^{2)}$ 。

病院が居住区域に立地している場合や、排気口の近くに人が近づ く可能性がある場合などは、排気の際に HEPA フィルターを設ける必 要がある。

付加的な殺菌装置としてUVGI（紫外線殺菌照射）を利用してもよ いが、補助的手段として用いるにとどめ、HEPAフィルターの代用と して用いてはならない。

[17] 病室および特定区域の排気口は建物の外気取入口や病室空から 離すこと ${ }^{2)}{ }^{3)}$ 。

排出した空気が再取り込みされないよう、排気口と外気取入口・ 空等の設置位置を計画すること。

[18］空調換気設備が停止した場合の対策を講じること ${ }^{3)}{ }^{5)}$ 。

給排気ダクトには室ごとに気密ダンパをつけ、ファン停止時には 連動して閉鎖する機構を備えることが望ましい5)。

(給水、排水等)

[19] 病室内に手洗い設備を設けること ${ }^{1)}{ }^{3)}$ 。

感染対策の基本となる手洗いを効果的に実施できるよう、病室内
には手洗い設備を設けること。

[20] 手洗い設備の水栓は、手の指を使わないで操作できるものが望 ましい ${ }^{1)}$ 。

感染対策上の理由から、手洗い設備は自動水栓など手の指を使わ ない構造とすることが望ましい1)。

[21］排水を適切に処理できる設備を有すること ${ }^{1}$ 。

公共下水道が整備されている地域では、直接の放流を行っても支 障はない2)。

(検査等)

[22] 結核患者が使用する検査室は陰圧とすること ${ }^{4)}$ 。

気管支内視鏡検查など、患者がマスクを外して検査を受ける検查 室から、空気が外部にもれないようにすること。

検査室の使用前に、室内が陰圧状態であることを確認し、記録を つけると。

[23] 採痰ブースは空気がもれない閉鎖空間とすること ${ }^{4)}$ 。

結核菌が多く排出される採痰ブースは陰圧とし、空気が外部に漏 れ出さないようにすること。

（運用における留意点）

[24]当該病室に結核患者を収容している間は、病室を陰圧状態に保 つため、空を開けないこと ${ }^{1)}$ 2)。また扉は出入り時以外閉めておくこ と ${ }^{2)}$ 。

病室からの飛沫核の拡散を最小限にするため、陰圧状態を保持す るための運用上の工夫をすること。

[25] 結核患者を収容している期間中は、病室および特定区域の陰圧 状態を毎日点検し、記録をつけること。

陰圧の確認は煙管または差圧計等によって行うこと。ただし差圧 計はその位置によって計測值が変わることに注意すること。煙管の 代用として、ベビーパウダー等を用いて空気流の状況を確認する方 法もある。差圧計によって陰圧の確認を行う場合、差圧計の動作確 認および点検を定期的に実施すること ${ }^{2)}$

患者を収容していない場合でも、病室の陰圧を定期的に（毎月） 点検すること ${ }^{2)}$ 。

[26] 診断治療の手技はできる限り当該病室内で行うこと ${ }^{2)}$ 。

結核患者が病室（特定区域）外に滞在・通過する機会を少なくす るため、必要な処置等はなるべく病室内にて行うようにする。

[27] 病室または特定区域内での長期間の隔離を強いられる患者の療 養環境に配慮すること ${ }^{2)}$ 。

病室内に電話・テレビ・ラジオ・インターネット等の設備を備え るなど、なるべく病室外に出ないようにするための、患者に対する 行動の動機付けが有効である ${ }^{2)}$

[28] 病室または特定区域に医療スタッフ・家族等が出入りする際に はN 95 マスク注9)を着用すること ${ }^{2)}$ 。

病室もしくは特定区域内に職員や患者家族等が立ち入る場合には、 N95 マスクを着用して感染を防御すること。

[29] 結核患者が病室もしくは特定区域の外へ出る場合には、サージ カルマスクを着用させること ${ }^{2)}$ 。

病室内で実施できない検査などのために、結核患者が病室（特定 区域）外一出る場合には、サージカルマスクを着用させて感染性飛 沫の飛散を防止すること。

[30］特定区域外の部屋を使用する際には、結核患者と他の患者を同 
時に入室させないようにすること ${ }^{3)}$ 。

結核患者が、放射線検査など病室で実施できない検査・診療に関 する諸室を使用する際は、利用時間帯を区分するなどして、結核患 者と他の患者が接触する機会を少なくすること。またエレベータや 廊下等においても、結核患者と一般の患者等との接触時間が短くな るよう、運用上の工夫をすること。

[31] HEPA フィルターの適切な保守管理を行うこと ${ }^{2)}$ 。

フィルターの性能について定期的に点検し、記録をつけること ${ }^{2)}$ 。

フィルターの維持管理作業は、専門知識を有する担当者が行うこ ととし、排気システム・再循環システムが稼働していない時に実施 すること。また保守点検時の安全性を確保するために、污染空気が 通過するフィルター収納部および収納部に接続するダクトには、「污 染空気」(または同様の警告)という標識をはっきりと表示すること2)。 [32］院内感染対策委員会による運用の評価を定期的に実施すること 2)。

院内感染対策委員会を設置し、結核の院内感染対策についての指 導・監督、運用状況の評価を定期的に行うこと。結核以外の感染症 を取り扱う院内感染対策委員会が同時に結核を取り扱うことでも良 いが、その場合には、結核の感染対策の責任者を決め、呼吸器を専 門とする医師を加えることが望ましい4)。

\section{3-2. 施設基準試案の解説}

前節で示した施設基準試案について、補足解説を加える。

\section{A. 病室の構成と特定区域の設定について}

結核は、他の感染症疾患と比較して入院期間が長いため、病室群 および共用空間からなる「特定区域」を設定し、患者の排菌状態に 応じて外出可能範囲が拡大寸るよう、段階的な空間構成とすること が望ましいと考える。この特定区域には、食堂や談話室など結核患 者が他の患者と共用することが困難な生活関連諸室が設けられるこ とを想定している。特定区域の面積や設備・しつらいについては、 収容する結核患者の人数に応じて、各医療機関において検討する必 要がある。

なお結核専門の医療機関においては、入院治療が数年に亘る多剂 耐性結核患者に対応できるよう、とくに患者の Q O L 確保に配慮し、 生活領域を広げることが可能な特定区域を設定することが望ましい と考える。

B. 前室について

結核患者を収容する病室において、前室は必ず設けなければなら ないものではないが、病室への出入り時に扉を開放する際、廊下へ 飛沫核が漏れる可能性を少なくする効果がある。特に白血病やH I $\mathrm{V}$ 感染などの合併症により、免疫力が低下して易感染状態にある患 者については、病室の空気圧設定に特別な配慮が必要となるため、 前室付き病室に収容するべきである。易感染状態にある結核患者を 収容する場合には、前室を廊下および病室に対して陽圧に設定する か、前室を廊下および病室に対して陰圧に設定することによって、 病室に清浄空気のみを取り入れつつ他の区域に結核菌を伝播しない ようにする必要がある。

\section{4. まとめと今後の展望}

文献調查および各分野の専門家による議論を踏まえて、結核患者 を収容するための医療機関の施設基準試案を提示した。
2 章で述べたように、この試案では、今後とくに必要性が高まる と思われる病室単位での結核患者収容の場合を念頭において議論を 行った。そのため、数年に亘る入院治療を要する多剂耐性結核の患 者を収容する医療機関についての検討が不十分であり、今後の課題 として残されている。

なお検討段階の議論において、「建築設備に関する施設基準は疾 患の感染経路に応じて定められるべき」との意見があった。感染症 法では、感染力の強さや致死率といった「脅威の度合い」によって 疾患が分類されている（表 2) が、それらの感染経路は様々である。 建築設備上の対応策は、空気感染・飛沫感染・接触感染といった感 染経路に応じて内容が異なるため、現行のように务威の度合いによ る疾患分類（一類・二類感染症）に対応させて収容病室（第一種・ 第二種病室）を設定することは、施設基準を策定する上では合理的 でないと思われる。

また、治療法や予防法の確立により、結核への対応方法が時代に より大きく変化してきたことを考えると、医療機関の施設基準は科 学的根拠に基づいて継続的に見直しを行う必要があると考える。

本稿で示した試案は研究班による議論の結果に過ぎないが、今後、 最新の知見による感染管理の観点と、結核患者の人権への配慮とい う観点から、適切な施設基準が策定されることを期待したい。

本稿は平成 20 年度厚生労働科学研究費補助金 ( 新興・再興感染症 研究事業）「我が国における一類感染症の患者発生時の臨床的対応に 関する研究」（主任研究者・工藤宏一郎・国立国際医療センター）の 分担研究として実施した「結核を想定した感染症指定医療機関の施 設基準に関する研究」（分担研究者・筧淳夫 - 国立保健医療科学院） の一部である。

\section{注}

注 1) 平成 20 年患者調查（厚生労衔省）の「傷病分類別入院患者数」によると、 総数 139 万 2 千人のうち結核による入院患者は 5 千人弱であり、全入院患者 の $0.3 \%$ に過ぎない状況となっている。

注 2) 感染症の感染経路には、飛沫核（5マイクロメートル以下の粒子）によ る「空気感染、微生物を含む飛沫が短い距離を飛んで伝播する「飛沫感染、 直接・間接に接触することによる「接触感染」とがある。

注 3) 本研究は以下のメンバーにより構成される研究班を組織して実施した (五十音順、所属は研究実施時のもの)。代表:筧淳夫（国立保健医療科学院）。 建築系研究協力者 : 伊藤昭 (日建設計)、系山剛（竹中工務店）、河口豊（広 島国際大学)、吉良悟（ＴＯＴＯ）、郡明宏（鹿島建設）、小林健一（国立保 健医療科学院)、阪田総一郎（高砂熱学工業）、辻吉隆（厚生労働省）、森本 正一 (新菱冷熱工業)、柳宇 (国立保健医療科学院)。医療系研究協力者 : 大 久保憲 (東京医療保健大学)、坂本史衣（聖路加国際病院）、吉山崇（結核予 防会複十字病院)。

注 4）室内一供給される空気で、外気と還気が含まれる。

注 5）室外一排出される空気のうち、屋外一排出される空気。

注 6）室外一排出される空気のうち、再循環する空気。

注 7) High Efficiency Particulate Air Filterの略称で、使い捨ての乾式夕 イプのフィルターのこと。固定した枠の中に入っており、0.3 $\mu \mathrm{m}$ エアゾル 粒子を $99.97 \%$ 捕集する能力を有する。フィルターの圧力低下は 1.0 インチ (2. $54 \mathrm{~cm})$ 水柱以下であること。試験粒子としては、これまで DOP (dioctyl phthalate) が用いられてきたが、人体への有害性が指摘され、安全性の 再評価を行って段階にある。今日では代替試駼粒子としてPOA(poly alpha olefin）が用いられている。HEPA フィルターの性能を維持するため、前置フ イルターを設置して運用することが望ましい。

注 8) UVGI はUltraviolet Germicidal Irradiation の略称。空気中に浮遊す る結核菌を殺菌する装置として、広く用いられている。ただし文献 2 等では、 
UVGI はあくまで補助的手段として用いるにとどめ、HEPA フィルターの代用 として用いてはならないとされている。結核菌は飛沫核単体ではなく埃に付 いた状態で浮遊しているため、紫外線照射の際に影が出来ることもあり、殺 菌効果に不確実性が残るとの指摘もある。

注9) 米国 National Institute of Occupational Safety and Health が定める N95 規格を満たすマスクで、 $0.1 \sim 0.3 \mu \mathrm{m}$ の微粒子を $95 \%$ 以上除去できる性 能を持つ。

\section{参考文献}

1) 厚生労働省健康局結核感染症課長 : 感染症指定医療機関の施設基隻に関する 手引きについて, H16.3. 3 健感発第 0303001 号, 2004

2) Centers for Disease Control and Prevention (CDC), U.S. Department of Health and Human Services : Guidelines for Preventing the Transmission of Mycobacterium tuberculosis in Health-Care Settings, 2005

3) 厚生労働省健康局長: 結核患者収容モデル事業実施要領の一部改正について, H16. 6.8 健発第 0608005 号, 2004

4) 森亨編：結核院内（施設内）感染予防の手引き, 財団法人結核予防会, 2000

5）日本医療福祉設備協会 : 病院空調設備の設計・管理指針（HEAS-02-2004）, 2004

6) Centers for Disease Control and Prevention (CDC), U.S. Department of Health and Human Services : Guideline for Isolation Precautions: Preventing Transmission of Infectious Agents in Healthcare Settings, 2007

7) AIA (American Institute of Architects) : Guidelines for Design and Construction of Health Care Facilities, 2006

8）島尾忠男：わが国の結核対策，財団法人結核予防会，1996

[2010 年 2 月 19 日原稿受理 2010 年 5 月 10 日採用決定］ 